\title{
Trends in the management of gastro-oesophageal reflux disease
}

\author{
John M Lee, Colm A O'Morain
}

\begin{abstract}
Summary
Gastro-oesophageal reflux disease is common, with up to $10 \%$ of the general population experiencing heartburn on a daily basis. It is a chronic condition and follow-up studies indicate the presence of symptoms at least 20 years after initial diagnosis. In addition to lifestyle modifications, management usually involves the use of an acid suppressant from the $\mathrm{H} 2$ receptor antagonist or proton pump inhibitor groups or a prokinetic agent at some stage. In terms of initial symptom resolution and mucosal healing the proton pump inhibitors are consistently superior to the other available agents. However, while it is possible to keep the majority of patients in remission while taking medications, almost all patients have a recurrence of symptoms within six months of stopping medications. The introduction of laparoscopic fundoplication has produced promising initial results but the long-term benefits of this procedure remain to be established. The role of Helicobacter pylori eradication in the management of gastro-oesophageal reflux disease needs further evaluation.
\end{abstract}

Keywords: gastro-oesophageal reflux disease; proton pump inhibitor; laparoscopic fundoplication; Helicobacter pylori; $\mathrm{H} 2-$ receptor antagonists

Department of Gastroenterology, Meath I Adelaide Hospitals, Trinity College, Dublin, Ireland

$\mathrm{J} M$ Lee

C A O'Morain

Correspondence to Prof Colm A O'Morain, Department of Gastroenterology, Meath Hospital, Heytesbury Street, Dublin 8, Ireland

Accepted 15 September 1997
Gastro-oesophageal reflux disease (GORD) is one of the most common conditions presenting to primary care physicians and gastroenterologists. It refers to the abnormal exposure of the oesophageal mucosa to refluxed gastric contents, including acid and pepsin, resulting in symptoms and/or tissue damage. Epidemiological studies suggest that between $21 \%$ and $44 \%$ of the adult population report heartburn, the predominant symptom of GORD, on a monthly basis, ${ }^{1-3}$ and between 4 and $10 \%$ of 'normal' adults experience heartburn on a daily basis. ${ }^{1-4}$ Symptoms of reflux are particularly common during pregnancy. Up to $25 \%$ of patients undergoing endoscopy for the assessment of dyspepsia will have evidence of oesophagitis. ${ }^{5}$ The prevalence of oesophagitis in the community is estimated to be up to $2 \% .{ }^{6}$ Evidence of oesophagitis is found in over $50 \%$ of patients presenting to a doctor with symptoms of GORD. ${ }^{8-11}$ Long-term follow-up studies looking at the natural history of GORD over periods of time from 10 to 22 years confirm that it is not a self-limiting condition and patients still have significant morbidity and impaired quality of life many years after their initial diagnosis. ${ }^{12}{ }^{13}$ GORD is thus a common condition and places a major burden on healthcare services worldwide. Changes in the management of GORD reflect the relatively recent availability of proton pump inhibitors and the introduction of laparoscopic antireflux surgery. In addition, the discovery of the role of Helicobacter pylori has changed our approach to the management of all patients presenting with dyspeptic symptoms.

\section{Symptomatology}

GORD has a broad spectrum of symptomatology. The most frequently documented symptoms include heartburn and acid regurgitation (box 1), but combinations of symptoms are common and many patients with heartburn are found to have other upper abdominal symptoms. When compared with prolonged ambulatory oesophageal $\mathrm{pH}$ monitoring, daily heartburn has a reported specificity of 69 to $89 \%$ for GORD. Daily regurgitation has an even higher specificity, ranging from 83 to $95 \% .{ }^{14}{ }^{15}$ Therefore, when these symptoms predominate, a confident diagnosis can often be made, and treatment commenced on the basis of history alone. However, the sensitivity of both symptoms is low ( $6 \%$ for regurgitation and $38 \%$ for heartburn) and reliance on this approach alone will result in many cases of GORD being undiagnosed. ${ }^{14}$ These low sensitivity figures are a reflection of the large proportion of GORD patients with atypical symptoms. ${ }^{16}{ }^{17} \mathrm{Up}$ to $50 \%$ of patients with evidence of oesophagitis at endoscopy present with atypical symptoms, ${ }^{17-19}$ including non-cardiac chest pain, hoarseness, nausea and respiratory problems (box 1). In addition, symptoms suggestive of GORD can be caused by other conditions such as ischaemic heart disease, cholelithiasis, peptic ulcer disease and oesophageal carcinoma.

The reported severity of symptoms does not correlate with the degree of oesophageal damage evident at endoscopy. ${ }^{17}{ }^{20}{ }^{21}$ Thus, patients with suspected GORD frequently need investigation. Patients with alarm symptoms such as dysphagia, weight loss, bleeding or anaemia always need investigation (box 2). The index of suspicion for more sinister diagnoses must be higher in patients over 45 years old.

\section{Investigations}

There are many tests available for the evaluation of patients with acid-reflux disorders (box 3). In an era when economic constraints are a major factor in the delivery of healthcare, it is increasingly emphasised that only investigations necessary to provide essential information for patient management should be performed. In young patients presenting with heartburn a therapeutic trial of an 


\begin{tabular}{|l|}
\hline Gastro-oesophageal reflux \\
disease: symptomatology \\
\hline Frequent symptoms \\
- heartburn \\
- acid regurgitation \\
- epigastric pain \\
belching \\
Atypical symptoms \\
- non-cardiac chest pain \\
- hoarseness \\
nausea \\
respiratory complaints: asthma, \\
nocturnal cough, wheeze, recurrent \\
pneumonia and lung abscesses \\
\hline
\end{tabular}

Box 1

\begin{tabular}{|l|}
\hline Gastro-oesophageal reflux \\
disease: alarm symptoms \\
\hline dysphagia \\
- odynophagia \\
- bleeding \\
- anaemia \\
weight loss \\
\hline
\end{tabular}

Box 2

\begin{tabular}{|l|} 
Gastro-oesophageal reflux \\
disease: investigation \\
\hline endoscopy ( \pm histology) \\
- oesophageal pH monitoring (24-h) \\
- barium swallow \\
- oesophageal manometry \\
\hline
\end{tabular}

Box 3

\section{Factors contributing to gastro-oesophageal reflux disease}

- oesophageal sphincter incompetence

- aggressive nature of refluxed material (acid, pepsin, bile)

- impaired clearance of refluxed material due to motility abnormalities

- impaired mucosal defence mechanisms

- delayed gastric emptying

- hiatus hernia

\section{Box 4}

\section{Goals of treatment}

- relief of symptoms

- healing of oesophageal mucosa

- prevention of complications

- maintenance of remission acid-suppressing agent is a reasonable initial step. However, if symptoms continue or the patient deteriorates, evaluation is necessary. All patients with alarm symptoms, irrespective of age, should have evaluation before therapy. Endoscopy is the investigation of choice for many clinicians. ${ }^{17}{ }^{19}$ It allows inspection of the mucosa and offers the opportunity to perform mucosal biopsies which can improve the sensitivity of the test, ${ }^{17}$ particularly when the mucosa is endoscopically normal. It also facilitates the diagnosis of other conditions such as oesophageal carcinoma and Barrett's mucosa. If more readily available, a barium study is an adequate alternative. Sensitivity is low in cases of mild oesophagitis, ${ }^{22}$ but if symptoms, such as dysphagia, suggesting luminal narrowing are present, a preliminary barium study is particularly helpful. Where endoscopy is negative and confirmation of the diagnosis is sought, or response to therapy is poor, ambulatory $\mathrm{pH}$ monitoring should be considered. Of all the available diagnostic tests it has the best sensitivity (81-96\%) and specificity $(96-100 \%),{ }^{17}$ and many would consider it the 'gold standard' in diagnosing GORD. In addition, ambulatory $\mathrm{pH}$ monitoring is also very helpful in the preoperative and postoperative assessment of patients undergoing antireflux surgery. ${ }^{23}$ Acid perfusion tests, ${ }^{24}$ and oesophageal manometry are less frequently used in clinical practice. Oesophageal manometry is recommended for patients before antireflux surgery, ${ }^{24}$ while it has to date contributed greatly in elucidating the role of transient lower oesophageal sphincter relaxation in the pathogenesis of GORD. ${ }^{25}$

\section{Pathophysiological basis for therapy}

Some degree of gastro-oesophageal reflux occurs in the normal population, particularly postprandially, and should be considered a benign physiological process. The proposed factors contributing to pathological gastro-oesophageal reflux include oesophageal sphincter incompetence ${ }^{25}{ }^{26}$ motility abnormalities causing impaired clearance of refluxed material, ${ }^{26}{ }^{27}$ the aggressive nature of refluxed material, ${ }^{26} 28$ impaired oesophageal epithelium defence mechanisms, ${ }^{26} 3031$ impaired gastric emptying, ${ }^{32}$ and finally, the presence of a hiatus hernia (box 4). The role of $H$ pylori infection in the pathophysiology of GORD is under evaluation, but evidence to date would suggest that the infection does not have a role, ${ }^{33} 34$ and indeed eradication may precipitate symptoms.

As in all areas of medical practice, management strategies in GORD should address the pathophysiological abnormalities underlying the clinical presentation, where possible. Foods known to decrease lower oesophageal sphincter pressure, including chocolate, peppermint and foods rich in fat, should be avoided..$^{35-38}$ Alcohol also adversely affects the lower oesophageal sphincter, and oesophageal peristalsis, and should thus be discouraged..$^{35}{ }^{40}$ Cigarette smoking should be avoided as it has been shown to decrease lower oesophageal sphincter pressure and also has deleterious effects on salivary function and mucosal resistance. ${ }^{35}$ In addition, many medications commonly used in the treatment of other medical conditions have been associated with altered lower oesophageal sphincter tone and should be avoided where possible. They include nitrates, theophyllines, oral contraceptives and calcium channel blockers, particularly nifedipine. Calcium channel blockers may also exacerbate reflux by adverse effects on acid clearance..$^{35}$

Despite the fact that acid hypersecretion is only seen in a minority of patients with GORD, ${ }^{42}{ }^{43}$ arguably most progress in the management of this condition has resulted from the development of agents which alter the aggressive nature of the refluxed material, especially the antisecretory properties of both the $\mathrm{H} 2$-receptor antagonists and the proton pump inhibitors. Acid and pepsin are both damaging to the oesophageal epithelium, and the damage is greater with both together than with either one alone. In addition, the presence of bile salts contributes to the damage. ${ }^{44}$ However, disordered motility, particularly transient relaxation of the lower oesophageal sphincter, is believed to be a more important factor than acid hypersecretion in the pathogenesis of GORD. The use of available prokinetic agents is mainly based on their ability to modifying oesophageal function by increasing lower oesophageal sphincter pressure and the amplitude of oesophageal contractions. They also enhance gastric emptying.

\section{Treatment of GORD in clinical practice}

Therapy should be initiated by recommending changes in lifestyle where appropriate. Many patients will have 'self-medicated', ${ }^{26}{ }^{45}$ with antacids prior to review so any further prescription will probably involve either a proton pump inhibitor, a H2-receptor antagonist or a prokinetic agent. Whatever management strategy is chosen, the aims/endpoints of treatment are the same (box 5). 


\begin{tabular}{|l|}
\hline Lifestyle advice \\
\hline - weight reduction if overweight \\
diet modification: avoid foods causing \\
symptoms, eg, fat, coffee, peppermint; \\
avoid eating $3 \mathrm{~h}$ before going to bed; \\
avoid large meals and large quantities \\
of liquid \\
- elevate head of bed \\
discourage smoking \\
reduction of alcohol intake \\
- avoid stooping and bending if possible \\
\hline
\end{tabular}

\section{Box 6}

\begin{tabular}{|l|}
\hline Management strategies \\
\hline 'Step-up' approach \\
- lifestyle modifications \\
- antacids \\
- H2-receptor antagonist or prokinetic \\
agent \\
- proton pump inhibitor \\
- combination therapy \\
- antireflux surgery \\
'Step-down' approach \\
- proton pump inhibitor \\
- H2-receptor antagonist or prokinetic \\
agent \\
- lifestyle modifications \\
'Single-agent' therapy \\
\hline
\end{tabular}

Box 7
SYMPTOM RESOLUTION AND MUCOSAL HEALING

H2-Receptor antagonists are the most commonly prescribed agents for the acute treatment of GORD, but are much less effective than proton pump inhibitors. Healing rates are inversely proportional to the severity of oesophagitis and, overall, $50-70 \%$ of patients have complete or partial resolution of symptoms. ${ }^{46}$ Symptom resolution does not always correlate with mucosal healing. Up to $20 \%$ of patients referred to gastroenterologists with GORD have complications such as ulceration, strictures or Barrett's mucosa and unfortunately such patients are particularly resistant to $\mathrm{H} 2$-receptor antagonist therapy. ${ }^{47}$ Tolerance to $\mathrm{H} 2$-receptor antagonists on repeated administration, and rebound on cessation of therapy may also occur. ${ }^{48}$ Proton pump inhibitors produce more profound suppression of acid and consistently achieve initial healing rates of over $90 \% .^{26}{ }^{49}$ In clinical trials the proton pump inhibitors are repeatedly superior to H2-receptor antagonists in terms of initial symptom relief and mucosal healing. ${ }^{50-56}$ A large percentage of patients who are resistant to therapy with H2-receptor antagonists can be healed with proton pump inhibitors. Very few studies have directly compared the efficacy of different proton pump inhibitors and to date no substantial difference has been detected in terms of overall symptom relief and mucosal healing. ${ }^{57-59}$ There is some evidence, however, that lansoprazole induces symptom relief more rapidly than omeprazole. ${ }^{57-59}$ Pantoprazole, one of the newer proton pump inhibitors, is reported to have a higher degree of pharmacokinetic precision and fewer potential drug interactions. Cisapride is the most commonly used prokinetic agent, and has been shown to be superior to placebo in several studies. ${ }^{60-63}$ It has also been shown to be as effective as $\mathrm{H} 2$-receptor antagonists in producing symptom relief. ${ }^{64-66} \mathrm{It}$ is potentially more effective when there is a nocturnal predominance of symptoms, and concurrent motility symptoms. ${ }^{26}$

\section{TREATMENT STRATEGIES ON INITIAL PRESENTATION}

Two main treatment strategies using the available agents have been advocated the 'step-up' approach and the 'step-down' approach. ${ }^{26}$ In the former strategy, management starts with life-style advice (box 6) and the withdrawal of medications which impair either lower oesophageal sphincter pressure, gastric emptying or mucosal resistance. Antacids are also prescribed at this stage, but many patients will have had a trial before presentation. If these initial steps are unsuccessful, treatment is increased with either a $\mathrm{H} 2$-receptor antagonist or a prokinetic agent. If symptoms still persist, proton pump inhibitors are advised. Factors in favour of this approach would be the avoidance of powerful acid suppression in a large proportion of patients with mild disease. It would also theoretically result in the minimal amount of expense to the healthcare system and seems appropriate for a primary care setting.

The 'step-down' approach involves a strategy of going directly to a 4-8 week course of profound acid suppression with an agent such as a proton pump inhibitor. It will often be the most appropriate approach for the patient with more severe symptoms and advanced endoscopy findings. It results in rapid symptom relief and healing of the mucosa. Treatment is later stepped down to either a H2-receptor antagonist or a prokinetic agent and lifestyle modifications are introduced. However, patients may be reluctant to give up the symptom relief they experienced with the proton pump inhibitor when the other agents are introduced. 'Single-agent' therapy, whereby the clinician relies upon the same agent for the treatment of all grades of oesophagitis, has also been proposed as a third potential strategy. However, such an approach cannot be recommended at this stage as the $\mathrm{H} 2$-receptor antagonists or the prokinetic agents are ineffective in up to $40 \%$ of patients when used alone, while proton pump inhibitors are more expensive and unnecessary in many patients with mild symptoms.

\section{MAINTENANCE OF REMISSION}

GORD is a chronic disease with the majority of patients having a relapse of symptoms on treatment withdrawal despite initial healing. ${ }^{67}{ }^{68} \mathrm{Up}$ to $20 \%$ of patients will develop complications relating to their disease. ${ }^{11}$ Maintenance therapy is thus an important issue and the minimal dose of drug capable of symptom relief and maintaining mucosal healing is considered the ideal for long-term treatment. The therapeutic options for maintaining remission include 'on demand' medical treatment, 'maintenance' medical treatment or antireflux surgery. On-demand therapy implies the episodic use of pharmacological agents for symptomatic relapse. This is a reasonable approach for patients with mild or infrequent symptoms and/or grade 1 reflux disease at endoscopy. Maintenance or continuous therapy is more likely to be necessary in patients with high-grade oesophagitis or complications such as strictures, ulceration or Barrett's mucosa. Factors which have been shown to predict a need for long-term therapy include 
the presence of severe symptoms, advanced endoscopic findings, oesophageal motility abnormalities, nocturnal symptoms and poor response to $\mathrm{H} 2$-receptor antagonists ${ }^{69} 70$ A number of agents have been used in maintenance therapy - the $\mathrm{H} 2$-receptor antagonists or the prokinetic agents used alone give remission rates of $60 \%$ at one year, while the figure for proton pump inhibitors is about $85 \% .^{26}$ All of these agents were recently compared in a 12-month follow-up study ${ }^{71}$ after initial healing with omeprazole. Patients received either cisapride alone, ranitidine alone, omeprazole alone, ranitidine plus cisapride, or omeprazole plus cisapride. Omeprazole, alone or in combination with cisapride, was more effective than any other regime. While the combination of a prokinetic agent and an antisecretory agent is theoretically appealing due to the multifactorial pathogenesis of GORD, the small benefits in maintaining remission evident in this study ( $80 \%$ vs $89 \%$ ) would suggest that such an approach would not be cost-effective for all patients. While there is little doubt about the efficacy of the proton pump inhibitors, some have expressed reservations about their use in the long-term. Observations to date are satisfactory, however, and up to 1995 more than 200 million patients worldwide had been treated with either omeprazole, lansoprazole or pantoprazole without severe side-effects. ${ }^{72}$ Some concern has also been expressed regarding the potential problems surrounding the effects of proton-pump-inhibitor-induced hypergastrinaemia ${ }^{73-75}$ on enterochromaffin-like cells, particularly in young patients, but to date these concerns have not been of significance in clinical practice. The monitoring of serum gastrin levels and fundic enterochromaffin-like cells is not advised in clinical practice, even during long-term proton pump inhibition. ${ }^{75}$

In addition to considering the effect of GORD on patients symptoms and quality of life, physicians are also expected to consider the cost-effectiveness of their treatment regimes. Harris et al recently assessed the cost-effectiveness of three different maintenance strategies after the initial healing of oesophagitis. In their model they considered (a) maintenance therapy with a proton pump inhibitor from the outset, $(b)$ maintenance therapy only if a patient's symptoms recur once over a year, and $(c)$ maintenance therapy only if a patient's symptoms recur twice over a year. Among their conclusions they suggest that maintenance therapy from the outset only appears cost-effective for patients with grade 4 oesophagitis, or those patients who report a significant decline in quality of life. For grade 2 and 3 oesophagitis, maintenance therapy after a patient experienced a recurrence of symptoms was their preferred option. ${ }^{76}$

\section{ANTIREFLUX SURGERY}

Surgery for gastro-oesophageal reflux has been performed for many years. Of the available operations, the 'floppy' Nissen fundoplication is the most widely used, and results in symptomatic and objective control of reflux in $91 \%$ and $83 \%$ of patients, respectively. ${ }^{77}$ There have been several modifications of the original procedure with some reduction in complications such as early dysphagia, longterm dysphagia and gas bloat. ${ }^{77}$ The laparoscopically performed Nissen fundoplication was first reported in $1991,^{78}$ and this undoubtedly has been the most exciting recent development in antireflux surgery. In the short term at least, similar results to the open procedure can be achieved, while the more rapid recovery time allows for a shorter hospital stay and a potentially shorter period of time off work. The success of these procedures is, however, operator dependent, and there is a strong case for concentrating this surgery in specialised centres. Patients need to be carefully selected for these procedures as a fundoplication is only going to be successful if the patients symptoms are definitely due to gastro-oesophageal reflux. Recommended evaluation procedures prior to surgery include endoscopy, oesophageal manometry, and 24-hour oesophageal $\mathrm{pH}$ monitoring. ${ }^{79}$ There have now been in the region of 6000 laparoscopic fundoplication procedures reported worldwide with an overall success rate of $90 \%{ }^{7}$ The mortality rate is less than $0.5 \%$ and the morbidity rate is estimated between 5 and $10 \% .{ }^{77}$ The long-term benefits of these procedures will not be known for another five to 10 years, but if the early results are maintained, laparoscopic antireflux surgery may well be a competitive cost-effective alternative to 'maintenance' medical therapy, particularly in young patients. This issue needs to be evaluated in further clinical trials.

Patient and physician acceptance of laparoscopic antireflux surgery has resulted in a greater number of patients being referred for surgery. Failure of medical therapy, including persistent symptoms of GORD, persistent oesophagitis and frequent relapses, are now the principal indications for antireflux surgery. In addition, antireflux surgery should be discussed with young patients who can only be maintained in remission with continued acid suppression, as patients are expressing a preference for surgery more frequently now. While they are not absolute indications for surgery, many gastroenterologists also feel that patients 
who develop complications of GORD such as Barrett's mucosa, aspiration, oesophageal ulcers, and strictures resistant to dilatation therapy are better managed with an operation. ${ }^{79}$

\section{Helicobacter pylori}

Since the discovery of Helicobacter pylori in the early 1980s, and its association with gastritis, it has since been firmly established that the eradication of the bacterium results in the cure of gastric and duodenal ulcers. The association between $H$ pylori and GORD has not been as well investigated. Theoretically, $H$ pylori-associated antral inflammation could increase the likelihood of GORD by delaying gastric emptying and increasing gastric acid output. In addition, proximal extension of the inflammatory process could interfere with 'valve mechanism' in the gastro-oesophageal area. Most studies to date, however, have just looked at the prevalence of $H$ pylori in patients with GORD, ${ }^{33}{ }^{34}$ and, in general, the prevalence of the infection is similar to that in control populations. These results would suggest that $H$ pylori probably does not have a role in the pathogenesis of GORD. However, it has recently been reported that patients with $H$ pylori infection requiring long-term proton pump inhibition for the treatment of GORD have an increased risk of developing atrophic gastritis, when compared to a group of patients who had undergone antireflux surgery. ${ }^{80}$ This could in turn result in an increased risk of gastric cancer development. The groups in this study were not age-matched, however, and the older age of the patients receiving drug therapy could in part explain these results. These initial findings certainly need further evaluation, but at this stage many groups would consider eradication of $H$ pylori before commencing long-term proton pump inhibition. In addition, therapy with proton-pump inhibitors alters the distribution of $H$ pylor in the stomach; the bacteria are usually most numerous in the antrum, but treatment with these agents increases the numbers in the fundus. ${ }^{83}$ This has implications for the diagnosis of $H$ pylori, as the sensitivity of diagnostic tests based on biopsies from the antrum alone would be less. In addition, there may well be pathological consequences with gastric ulcers and gastric cancers thought to be more common in patients with a pangastritis. On the other hand, there is some evidence to suggest that, in the absence of $H$ pylori infection, the proton pump inhibitors may not achieve sufficient inhibition of gastric acid output for the optimal treatment of GORD. The elevation of $\mathrm{pH}$ achieved by these agents is less marked when the organism is absent. ${ }^{81}{ }^{82} \mathrm{It}$ is clear that the role of $H$ pylori in both the pathogenesis and treatment of GORD needs further evaluation. The European Helicobacter pylori Study Group recently considered it 'advisable' on the basis of 'supportive' evidence, that $H$ pylori should be eradicated when GORD requires long-term treatment with proton pump inhibitors. ${ }^{84} 85$

1 Nebel OT, Fornes MF, Castell DO. Symptomatic gastroesophageal reflux: incidence and precipitating factors. Am $\mathcal{F}$ Dig Dis 1976;21:953.

2 Anonymous. Heartburn across America: a Gallup Organisation survey. Princeton, NJ: The Gallup Organisation, 1988.

3 Isolauri J, Laippala P. Prevalence of symptoms suggestive of gastroesophageal reflux disease in an adult population. Ann Med 1995;27:67-70.

4 Thompson WG, Heaton KW. Heartburn and globus in apparently healthy people. Can Med Assoc F 1982;126:46-8.

5 Richter JE. Dyspepsia: organic causes and differential characteristics from functional dyspepsia. Scand $尹$ Gastroenterol 1991;26(suppl 182):11-6.

6 Wienbeck M, Barnett J. Epidemiology of reflux disease and reflux oesophagitis. Scand $\mathcal{F}$ Gastrodisease and reflux oesophagitis.
enterol 1989;24(suppl 156):7-13.

7 Spechler SJ. Epidemiology and natural history of gastro-oesophageal reflux disease. Digestion 1992;51(suppl 1):24-9.

8 Bechar J, Biancani P, Sheahan DG. Evaluation of oesophageal tests in the diagnosis of reflux oesophagitis. Gastroenterology 1976;71:9-15.

9 Johansson K-E, Ask P, Boeryd B, Frannson $S-G$, Tibbling L. Oesophagitis, signs of reflux and gastric acid secretion in patients with symptoms of gastroesophageal reflux

10 Knill-Jones RP, Card WI, Crean GP, James WB, Spiegelhalter DJ. The symptoms of gastroSpiegelhalter DJ. The symptoms of gastro-
oesophageal reflux and of oesophagitis. Scand $\mathcal{f}$ Gastroenterol 1984;19(suppl 106):72-6.

11 Little AG, De Meester TR, Kirchner PT O'Sullivan GC, Skinner DB. Pathogenesis of esophagitis in patients with gastroesophageal reflux. Surgery 1980;88:101-7.

12 McDoughall NI, Johnston BT, Kee F, Collins JSA, McFarland RJ, Love AHG. Natural history of reflux oesophagitis: a 10 year follow up of its effect on patient sympto
life. Gut $1996 ; 38: 481-6$.

13 Isolauri J, Luostarinen M, Isolauri E, Reinikainen $P$, Viljakka $M$, Keyrilainen $O$. Natura course of gastroesophageal reflux disease: $17-22$ year follow-up study of 60 patients. $A m ~ f$ Gastroenterol 1997;92:37-41.

14 Klauser AG, Schindlbeck NE, Muller-Lissner SA. Symptoms in gastro-oesophageal reflux disease. Lancet 1990;335:205-8.

15 Johnsson F, Joelsson B, Gudmundsson K, Greiff L. Symptoms and endoscopic findings in the diagnosis of gastroesophageal reflux disease. diagnosis of gastroesophageal reflux

16 Bald F, Ferrarini F, Labate AMM, Barbara L Prevalence of oesophagitis in patients undergoing routine upper endoscopy: a multicentre survey in Italy. In: DeMeester TR, Skinner DB eds. Esophageal disorders. New York: Raven Press, 1985; pp 213-9.

17 McDougall NI. Diagnosis of reflux disease. Irish f Med Sci 1996;165:185-93.

18 Richter JE, Castell DO. Gastroesophageal reflux: pathogenesis, diagnosis and therapy. Ann Intern Med 1982;97:93-103.

19 Galmiche JP, Des Varannes B. Symptoms and disease severity in gastro-oesophageal reflux disease. Scand $f$ Gastroenterol 1994;29(suppl 201):62-8.

20 Eriksen CA, Cuschieri A. Diagnostic tests for gastro-oesophageal reflux disease. In: Hennessy TPJ, Cuschieri A, Bennet JR, eds. Reflux oesophagitis. London: Butterworths, 1989; pp 55-86.

21 Armstrong D, Fraser R. Diagnosis and assessment of gastro-oesophageal reflux disease. Gullet 1993; 3(suppl 1):31-41.

22 Blackwell JN. Investigation of the oesophagus. In: Misiewicz JJ, Pounder RE, Venables CW, eds. Diseases of the gut and pancreas. 2nd edn. Oxford: Blackwell Scientific Publications, 1994 pp 115-22.

23 Richardson WS, Trus TL, Hunter JG. Laparoscopic antireflux surgery. Surg Clin North Am 1996;76:437-50.

24 Bernstein LM, Baker LA. A clinical test for esophagitis. Gastroenterology 1958;34:760-81.

25 Dent J, Holloway RH, Toouli J, Dodds WJ. Mechanisms of lower oesophageal sphincter incompetence in patients with symptomatic gastro-oesophageal reflux. Gut 1988;29:1020-8.

26 Tytgat GNJ, Janssens J, Reynolds JC, Weinbeck $M$. Update on the pathophysiology and man$\mathrm{M}$. Update on the pathophysiology and man-
agement of gastro-oesophageal reflux disease the role of prokinetic therapy. Eur $\mathcal{f}$ Gastroenterol the role of prokinetic ther
Hepatol 1996;8:603-11.

27 Stanciu C, Bennet JR: Oesophageal acid clearing: one factor in the production of reflux oesophagitis. Gut 1974;15:852-7.

28 Orlando RC: Pathophysiology of gastrooesophageal reflux. Oesophageal epithelial resistance. In: Castell DO, ed, The oesophagus. New York: Little Brown, 1992; pp 463-78.

29 Safaie Shirazi S, Den Besten L, Zike WL. Effect of bile salts on the ionic permeability of the oesophageal mucosa and their role in the production of oesophagitis. Gastroenterology production of $1975 ; 68: 728-33$.

30 Jankowski J, Murphy S, Coghill G, et al. Epidermal growth factors in the oesophagus. Gut 992;33:439-3

31 Orlando RC, Bryson JC, Powell DW. Mechanisms of $\mathrm{H}+$ injury in rabbit oesophageal epithelium. Am $\mathcal{F}$ Physiol 1984;246:G718-724.

32 Cunningham KM, Horowitz M, Riddell PS, al. Relations among autonomic nerve dysfunction oesophageal motility and gastric emptying in gastro-oesophageal reflux disease. Gut 1991; 32:1436-40. 
33 O'Connor HJ, Cunnane K. Helicobacter pylori and gastro-oesophageal reflux disease prospective study. Irish $f \mathrm{Med} S \mathrm{Si} 1994 ; 163$. 369-73.

34 Liston R, Pitt MA, Banerjee AK. Reflux oesophagitis and Helicobacter pylori in elderly patients. Postgrad Med $¥$ 1996;72:221-3.

35 Kitchin LI, Castell DO. Rationale and efficacy of conservative therapy for gastroesophageal of conservative therapy for gastroesophageal reflux

36 Richter JE, Castell DO. Drugs, foods, and other substances in the cause and treatment of reflux oesophagitis. Med Clin North Am 1981;65: 1223-33.

37 Babka JC, Castell DO. On the genesis of heartburn: the effects of specific foods on the lower esophageal sphincter. Dig Dis 1973;18: 391-7.

38 Wright LE, Castell DO. The adverse effect of chocolate on lower esophageal sphincter pressure. Dig Dis 1975;20:703-7.

39 Hogan WJ, Viegas de Andrade SR, Winship DH. Ethanol-induced acute esophageal dysDH. Ethanol-induced acute esophageal
function. $\mathcal{F}$ Appl Physiol 1972;32:755-60.

40 Vitale G, Chesdle WG, Patel B, et al. The effect of alcohol on nocturnal gastroesophageal reflux. of alcohol on nocturnal ga

41 Richter JE. A critical review of current medical therapy for gastroesophageal reflux. $\mathcal{F}$ Clin Gastroenterol 1986;8(suppl 1):72-80.

42 Dent J. Roles of gastric acid and $\mathrm{pH}$ in the pathogenesis of gastro-oesophageal reflux disease. Scand $₹$ Gastroenterol 1994; 29(suppl 201): 55-61.

43 Collen MJ, Johnson DA, Sheridan MJ. Basal acid output and gastric acid hypersecretion in gastro-oesophageal reflux disease. Correlation with ranitidine therapy. Dig Dis Sci 1994;39: with rani $410-7$.

44 Safai-Shirazi S, DenBesten L, Zike WL. Effect of bile salts on the ionic permeability of the
oesophageal mucosa and their role in the production of oesophagitis. Gastroenterology 975;68:728-33.

45 Sontag SJ. Rolling review: gastrooesophageal reflux disease. Aliment Pharmacol Ther 1993;7: 293-312.

46 Collins JSA. Medical management of gastrooesophageal reflux disease. Irish $\mathcal{f} \mathrm{Med} S \mathrm{Sc}$ 1996;165:191-2.

47 Koelz HR: Treatment of reflux oesophagitis with $\mathrm{H} 2$-blockers, antacids and prokinetic drugs. Scand $\mathcal{F}$ Gastroenterol 1989;24(suppl 156):25-36.

48 Wilder-Smit $\mathrm{CH}$, Merki HS. Tolerance during dosing with $\mathrm{H} 2$ receptor antagonists: an overview. Scand $\mathcal{f}$ Gastroenterol 1992;27 (suppl 193): view.

49 Hunt RH, Cedarberg C, Dent J, et al. Optimising acid suppression for treatment of acidrelated disorders. Dig Dis Sci 1995;40(suppl 2):S24-49.

50 Robinson M, Decktor DL, Maton PN, et al. Omeprazole is superior to ranitidine plus metoclopramide in the short-term treatment of erosive oesophagitis. Aliment Pharmacol Ther 1993;7:67-73.

51 Vantrappen G, Rutgeerts L, Schurmans P, Coenegrachts J-L. Omeprazole $(40 \mathrm{mg})$ is superior to ranitidine in short-term treatment of ulcerative reflux esophagitis. Dig Dis Sci 1988; ulcerative
52 Bate CM, Keeling PW, O'Morain C, et al. Comparison of omeprazole and cimetidine in reflux esophagitis: symptomatic, endoscopic, and histological evaluations. Gut 1990;31:968-72.

53 Robinson M, Sahba B, Avner D, Jhala N, Greski-Rose PA, Jennings DE. A comparison of lansoprazole and ranitidine in the treatment of lansoprazole and ranitidine in the treatment of erosive esoph

54 Sandmark S, Carlsson R, Fausa O, Lundell L. Omeprazole or ranitidine in the treatment of reflux oesophagitis. Scand $\mathcal{F}$ Gastroenterol 1988, 23:625-32.

55 Bardhan KD, Hawkey CJ, Long RG, et al. Lansoprazole versus ranitidine for the treatment of reflux oesophagitis. Aliment Pharmacol Ther 1995;9:145-52.

56 Koop H, Schepp W, Dammann HG, Schneider A, Luhmann R, Classen M. Comparative trial of pantoprazole and ranitidine in the treatment of reflux esophagitis. $\mathcal{F}$ Clin Gastroenterol 1995;20 $192-5$

57 Hatlebakk JG, Berstad A, Carling L, et al. Lansoprazole versus omeprazole in short-term treatment of reflux oesophagitis. Scand $\mathcal{F}$ Gastroenterol 1993;28:224-8.

58 Mee AS, Rowley JL, and the Lansoprazole clinical research group. Rapid symptom relief in reflux oesophagitis: a comparison of lansoprazole and omeprazole. Aliment Pharmacol Ther zole and omeprazol

59 Castell DO, Richter JE, Robinson M, Sontag SJ, Haber $M M$ and the Lansoprazole group. Efficacy and safety of lansoprazole in the treatment of erosive reflux esophagitis. $A m \mathscr{F}$ Gastroenterol 1996;91:1749-57.

60 Mossner J, Holscher AH, Herz R, Schneider A. A double-blind study of pantoprazole and omeprazole in the treatment of reflux oesophagitis: a multicentre trial. Aliment Pharmacol Ther 1995; 9:321-6.

61 Collins BJ, Spence RAJ, Ferguson R. Cisapride: influence on oesophageal and gastric emptying and gastro-oesophageal reflux in patients with gastro-oesophageal reflux disease. Hepatogastroenterology 1987;34:113-6.

62 Nicolaidas CL, Kehagioglou K, Mantzaris G, al. Therapeutic effect of two doses of cisapride in controlling chronic reflux symptoms in oesophagitis patients. Curr Ther Res 1987;42: 1059-65.

63 Van Outryve M, Vanderlinden I, Dedullen G, Rutgeerts L. Dose-response study with cisapride in gastro-oesophageal reflux disease. Curr Ther Res 1988;43:408-15.

64 Janisch H, Hutteman W, Bouzo MH. Cisapride versus ranitidine in the treatment of reflux oesophagitis. Hepatogastroenterology 1988;35: 125-7.

65 Geldof H, Hazalhoff B, Otten MH. Two different dose regimens of cisapride in the treatment of reflux oesophagitis: a double-blind comparison with with ranitidine. Aliment Pharmacol Ther 1993;7:409-15.

66 Maleev A, Mendizova A, Popov P, et al. Cisapride and cimetidine in the treatment of erosive esophagitis. Hepatogastroenterology 1990; 37:403-7.

67 Hetzel DJ, Dent J, Reed WD, et al. Healing and relapse of severe peptic oesophagitis after treatment with omeprazole. Gastroenterology 1988; 95:903-12.
68 Glise H. Healing, relapse rates and prophylaxis of reflux oesophagitis. Scand $\mathcal{f}$ Gastroenterol 1989;156(suppl):57-64.

69 Schindelbeck NE, Klauser AG, Berghamme AG, Londong W, Muller-Lissner SA. Three year follow-up of patients with gastrooesophageal reflux disease. Gut 1992;33:10169.

70 Kuster E, Ros E, Toledo-Pimeltel V, et al. Predictive factors of the long-term outcome in gastro-oesophageal reflux disease: six year follow-up of 107 patients. Gut 1994;35:8-14.

71 Vigneri S, Termini R, Leandro G, et al. A comparison of five maintenance therapies for reflux esophagitis. N Engl f Med 1995;333:1 106-10.

72 Brunner G. Proton-pump inhibitors are the treatment of choice in acid-related disease. Eur 7 Gastroenterol Hepatol 1996;8(suppl 1):S9-13.

73 Brunner G, Creutzfeldt W. Omeprazole in the long-term treatment of patients with acidrelated disease resistant to ranitidine. Scand $\mathcal{F}$ Gastroenterol 1989;24(suppl 166):101-5.

74 Colin-Jones DG. Safety of lansoprazole. Aliment Pharmacol Ther 1993;7(suppl 1):56-60.

75 Arnold R. Safety of proton pump inhibitors - an overview. Aliment Pharmacol Ther 1994;8(suppl 1):65-70.

76 Harris RA, Kupperman M, Richter JE. Prevention of recurrences of erosive reflux esophagitis: a cost-effective analysis of maintenance proton pump inhibition. Am f Med 1997;102:78-88.

77 Watson A. Surgical management of gastrooesophageal reflux disease. Br $\mathcal{F}$ Surg 1996;83: 1313-5.

78 Geagea T. Laparoscopic Nissen fundoplication: preliminary report of ten cases. Surg Endosc 1991;5:170-3.

79 Richardson WS, Trus TL, Hunter JG. Laparoscopic antireflux surgery. Surg Clin North Am 1996;76:437-50.

80 Kuipers EJ, Lundell L, Klingenberg-Knoll EC et al. Atrophic gastritis and Helicobacter pylori infection in patients with reflux oesophagitis treated with omeprazole or fundoplication. $N$ Engl f Med 1996;334:1018-22.

81 Bell NJ, Burget D, Howden CW, Wilkinson J, Hunt RH. Appropriate acid suppression for the management of gastro-oesophageal reflux disease. Digestion 1992;51(suppl 1):59-67.

82 Labenz J, Tillenburg B, Peitz U, et al. Helicobacter pylori the $\mathrm{pH}$ increasing effect of omeprazole in patients with duodenal ulcer. Gastroenterology 1996;110:725-32.

83 Logan RPH, Walker MM, Misiewicz JJ, Kirk GE, Hawkey CJ, Spiller RC. Changes in the intragastric distribution of Helicobacter pylori during treatment with omeprazole. Gut 1995; 36:12-6.

84 The European Helicobacter pylori Study Group (EHPSG). Current European concepts in the management of $\mathbf{H}$ pylori infection - the Maastricht Consensus Report. Gut 1997;41: 8-13.

85 Malfertheiner P, Megraud F, O'Morain C, et al, for the European Helicobacter pylori Study Group (EHPSG). Current European concepts in the management of $H$ pylori infection - the Maastricht Consensus Report. Eur $\mathcal{f}$ GastroenMaastricht Consensus R
terol Hepatol 1997;9:1-2. 